\title{
Match analysis in football: a systematic review
}

ARTICLE in JOURNAL OF SPORTS SCIENCES · DECEMBER 2014

Impact Factor: 2.1 · DOI: 10.1080/02640414.2014.898852 · Source: PubMed

CITATIONS

11

6 AUTHORS, INCLUDING:

Rui Marcelino

Universidade de Trás-os-Montes e Alto Douro

68 PUBLICATIONS 240 CITATIONS

$$
\text { SEE PROFILE }
$$

Jorge Campanico

Universidade de Trás-os-Montes e Alto Douro

39 PUBLICATIONS 53 CITATIONS

SEE PROFILE
DOWNLOADS

1,282
VIEWS

720
M Teresa Anguera

University of Barcelona

53 PUBLICATIONS 193 CITATIONS

SEE PROFILE

José Leitão

Universidade de Trás-os-Montes e Alto Douro 59 PUBLICATIONS 104 CITATIONS

SEE PROFILE 
This article was downloaded by: [b-on: Biblioteca do conhecimento online IPV], [Jorge Arede]

On: 01 May 2014, At: 09:39

Publisher: Routledge

Informa Ltd Registered in England and Wales Registered Number: 1072954 Registered office: Mortimer House, 37-41 Mortimer Street, London W1T 3J H, UK

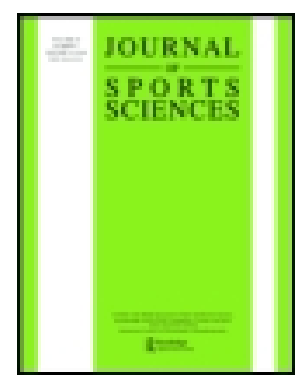

\section{J ournal of Sports Sciences}

Publication details, including instructions for authors and subscription information: http:// www.tandfonline.com/loi/ rjsp20

\section{Match analysis in football: a systematic review}

Hugo Sarmento ${ }^{a}$, Rui Marcelino ${ }^{b}$, M. Teresa Anguera ${ }^{c}$, J orge Campaniço ${ }^{d}$, Nuno Matos ${ }^{e} \&$ J osé Carlos Leitão ${ }^{d}$

${ }^{a}$ Department of Sport Sciences and Physical Education, University Institute of Maia, Maia, Portugal

${ }^{\mathrm{b}}$ Faculty of Sport, University of Porto, Porto, Portugal

${ }^{c}$ Department of Methodology of Behavioral Sciences, University of Barcelona, Barcelona, Spain

${ }^{\mathrm{d}}$ Department of Sport Sciences, Exercise and Health, University of Trás-os-Montes e Alto Douro, Vila Real, Portugal

${ }^{\mathrm{e}}$ Faculty of Sport Sciences, University of Coimbra, Coimbra, Portugal

Published online: 01 May 2014.

To cite this article: Hugo Sarmento, Rui Marcelino, M. Teresa Anguera, J orge Campaniço, Nuno Matos \& J osé Carlos Leitão (2014): Match analysis in football: a systematic review, J ournal of Sports Sciences, DOI: 10.1080/ 02640414.2014.898852

To link to this article: http:// dx. doi.org/ 10.1080/02640414.2014.898852

\section{PLEASE SCROLL DOWN FOR ARTICLE}

Taylor \& Francis makes every effort to ensure the accuracy of all the information (the "Content") contained in the publications on our platform. However, Taylor \& Francis, our agents, and our licensors make no representations or warranties whatsoever as to the accuracy, completeness, or suitability for any purpose of the Content. Any opinions and views expressed in this publication are the opinions and views of the authors, and are not the views of or endorsed by Taylor \& Francis. The accuracy of the Content should not be relied upon and should be independently verified with primary sources of information. Taylor and Francis shall not be liable for any losses, actions, claims, proceedings, demands, costs, expenses, damages, and other liabilities whatsoever or howsoever caused arising directly or indirectly in connection with, in relation to or arising out of the use of the Content.

This article may be used for research, teaching, and private study purposes. Any substantial or systematic reproduction, redistribution, reselling, loan, sub-licensing, systematic supply, or distribution in any form to anyone is expressly forbidden. Terms $\&$ Conditions of access and use can be found at http:// www.tandfonline.com/page/terms-and-conditions 


\title{
Match analysis in football: a systematic review
}

\author{
HUGO SARMENTO $^{1 \star}$, RUI MARCELINO ${ }^{2}$, M. TERESA ANGUERA ${ }^{3}$, JORGE \\ CAMPANIÇO $^{4}$, NUNO MATOS ${ }^{5}$ AND JOSÉ CARLOS LEITÃO ${ }^{4}$ \\ ${ }^{1}$ Department of Sport Sciences and Physical Education, University Institute of Maia, Maia, Portugal, ${ }^{2}$ Faculty of Sport, \\ University of Porto, Porto, Portugal, ${ }^{3}$ Department of Methodology of Behavioral Sciences, University of Barcelona, Barcelona, \\ Spain, ${ }^{4}$ Department of Sport Sciences, Exercise and Health, University of Trás-os-Montes e Alto Douro, Vila Real, Portugal \\ and ${ }^{5}$ Faculty of Sport Sciences, University of Coimbra, Coimbra, Portugal
}

(Accepted 24 February 2014)

\begin{abstract}
The main focus of this paper was to review the available literature on match analysis in adult male football. The most common research topics were identified, their methodologies described and the evolutionary tendencies of this research area systematised. A systematic review of Institute for Scientific Information (ISI) Web of Knowledge database was performed according to PRISMA (Preferred Reporting Items for Systematic reviews and Meta-analyses) guidelines. The following keywords were used: football and soccer, each one associated with the terms: match analysis, performance analysis, notational analysis, game analysis, tactical analysis and patterns of play. Of 2732 studies initially identified, only 53 were fully reviewed, and their outcome measures abstracted and analysed. Studies that fit all inclusion criteria were organised according to their research design as descriptive, comparative or predictive. Results showed that 10 studies focused predominantly on a description of technical, tactical and physical performance variables. From all comparative studies, the dependent variables more frequently used were "playing position" and "competitive level". Even though the literature stresses the importance of developing predictive models of sports performance, only few studies $(n=8)$ have focused on modelling football performance. Situational variables like game location, quality of opposing teams, match status and match half have been progressively included as object of research, since they seem to work as effective covariables of football performance. Taking into account the limitations of the reviewed studies, future research should provide comprehensive operational definitions for the studied variables, use standardised categories and description of activities and participants, and consider integrating the situational and interactional contexts into the analysis of football performance.
\end{abstract}

Keywords: game analysis, soccer, performance, review

\section{Introduction}

To better understand the constraints that promote sporting success, match analysis has assumed a very important role in sports games (Carling, 2009). In football, match performance can be defined as the interaction of different technical, tactical, mental (Carling, 2009) and physiological factors (Drust, Atkinson, \& Reilly, 2007).

Although one of the first works in this area of research was published in 1910 by Hugh Fullerton, the scientific research carried out was minimal during the following decades. This limited research production was among other reasons behind the lack of scien- tific journals on the subject (Hughes \& Franks, 2004a). Since the 1990s, however, and through the creation of international scientific societies (e.g., International Society of Performance Analysis of Sport), the edition of specialised scientific journals (e.g., International Fournal of Performance Analysis in Sport; Fournal of Quantitative Analysis in Sports) and the introduction of world conferences on notational analysis (currently named, "World Congress of Performance Analysis in Sport"), match analysis has gained a more prominent place in the scientific literature.

More recently, there have been specific edited books (Carling, 2009, 2005; Hughes, 1997, 2008;

${ }^{\star}$ Correspondence: Hugo Sarmento, Escola Superior de Educação de Viseu, Rua Maximiano Aragão, $3504-501$ Viseu, Portugal.

E-mail: hg.sarmento@gmail.com

Present affiliation for Hugo Sarmento is Centre for the Study of Education, Technologies and Health (CI\&DETS), Polytechnic Institute of Viseu - School of Education, Viseu, Portugal

Present affiliation for Rui Marcelino is Research Center in Sports, Health Sciences and Human Development (CIDESD), University of Trás-os-Montes e Alto Douro, Vila Real, Portugal 
Hughes \& Franks, 2004b; Reilly, 1977), and a significant amount of original research papers in scientific journals. However, despite an increase in the amount of research, there are still only a few systematic reviews available on match analysis, specifically in football.

The purpose of this study was therefore to systematically review and organise the literature on match analysis in adult male football as an attempt to identify the most common research topics, to characterise their methodologies and to systematise the evolutionary tendencies on this topic.

\section{Methods}

A systematic review of the available literature on match analysis in adult male football was conducted according to PRISMA (Preferred Reporting Items for Systematic reviews and Meta-analyses) guidelines. Three independent reviewers separately conducted the analysis (HS, RM, JL) performed on 4 November 2011.

In order to ensure the quality of articles, the electronic database Institute for Scientific Information (ISI) Web of Knowledge was researched for relevant publications prior to 4 November 2011, using the keywords football and soccer, each one associated with the terms: match analysis, performance analysis, notational analysis, game analysis, tactical analysis and patterns of play.

The inclusion criteria for these articles were: (1) relevant data concerning technical and tactical evaluation or statistical compilation, and time-motion analysis; (2) performed by amateur and/or professional adult male footballers and (3) written in English language. Studies were excluded if they: (1) included children or adolescents (under 18 years); (2) included females; (3) did not include any relevant data and (4) were conference abstracts. If there was disagreement amongst authors regarding the inclusion of certain articles, the final decision was left to the senior author (JL) due to greater experience on these matters.

To organise the results, the studies were grouped according to the major research topics of match analysis that emerged from the detailed analysis, and to the methodological strategies used.

\section{Results}

The initial search identified 2732 titles in the described database. After importing all references found using a reference manager software (EndNote X4, Thomson Reuters, Philadelphia, PA, USA), duplicates them (792 references) and papers from non-sport science-specific journals (1550 references) were eliminated either automatically or manually. The remaining 390 articles were then screened for relevance based on their title and abstract, resulting in another 279 studies being eliminated from the database. The full text of the remaining 111 articles was then read and another 58 were rejected due to a lack of relevance to the purpose of this study. At the end of the screening procedure, only 53 articles remained for the systematic review (Figure 1).

The chronological analysis of the articles published not later than year 2011 that comprise this review work evidenced the recent development in this area of research, highlighting that almost half $(45 \%)$ of the studies were published in the last two years (i.e., years 2010 and 2011).

After in-depth analysis, it was decided that the most appropriate way to present the results would be to categorise them as suggested by Marcelino, Mesquita, and Sampaio (2011). Based on this categorisation system, a new system was created resulting in the categorisation of material as a

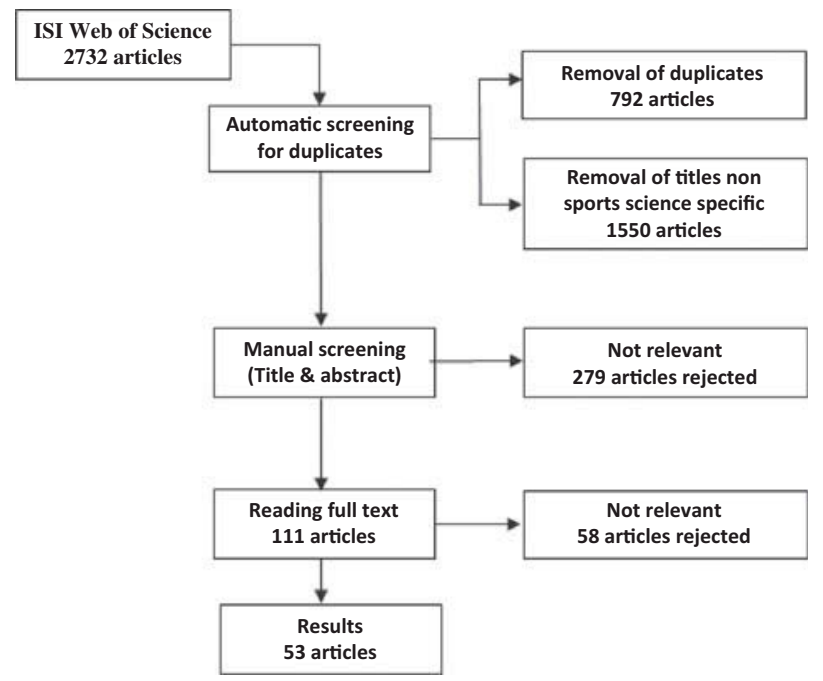

Figure 1. Flow chart of methodology used for the article search. 
function of two levels of analysis: a first-order level, depending on the type of analysis performed (descriptive analysis, comparative analysis and predictive analysis); and a second-order level, depending on the type of variables analysed (Figure 2).

\section{Discussion}

\section{Descriptive analysis}

The common aim of many of these reviewed papers is to describe the activity patterns of players (Table I). However, there are some exceptions. Carey et al. (2001) analysed the footedness of 236 players in the 16 teams of the 1998 World Cup finals in France. These researchers found no evidence that these players differed in any way from the rest of the population regarding their degree of right-footedness as measured by their choices on the pitch. De Baranda, Ortega, and Palao (2008) analysed the characteristics of goalkeepers' defensive interventions together with the type of opponent attack. Their results showed that the opposing teams used positional attacks more frequently and had the final pass coming from the far zones of the field. Goal saving and control with the feet were the most frequently used actions by goalkeepers, together with displacement before performing technical movements/skills.

Regarding time-motion analysis, studies were grouped by movement categories according to their intensity, ranging from five to seven categories from "standing" to "sprinting", trying to characterise the physical requirements in football. In general, these studies have shown that elite players normally covered distances between 9 and $14 \mathrm{~km}$, and performed approximately 1330 activities during a match, including 220 displacements at high speed (Barros et al., 2007; Di Salvo et al., 2007; Lago, Casais, Dominguez, \& Sampaio, 2010; Rampinini et al., 2007).

Given the specificity of the goalkeepers' activity, these players were also targeted for a similar analysis (De Baranda et al., 2008). It was found that goalkeepers $(n=62)$ covered a total distance of $5611 \pm$ $613 \mathrm{~m}$ per match, of which $4025 \pm 440 \mathrm{~m}$ were covered walking, $1223 \pm 256 \mathrm{~m}$ jogging, $221 \pm 90$ $\mathrm{m}$ running, $56 \pm 34 \mathrm{~m}$ at high intensity while the distance covered in sprinting was $11 \pm 12 \mathrm{~m}$.

\section{Comparative analysis}

Different playing position. The relationship between the player's positional role and performance was frequently studied (Table II). In these investigations, the authors attempted to group players according to different criteria, which made it difficult to compare accurately the results. Therefore, it seemed consensual to group players according to three major groups: defenders, midfielders and forwards. Based on these functional positions, researchers seek to find relationships that are established with physical-

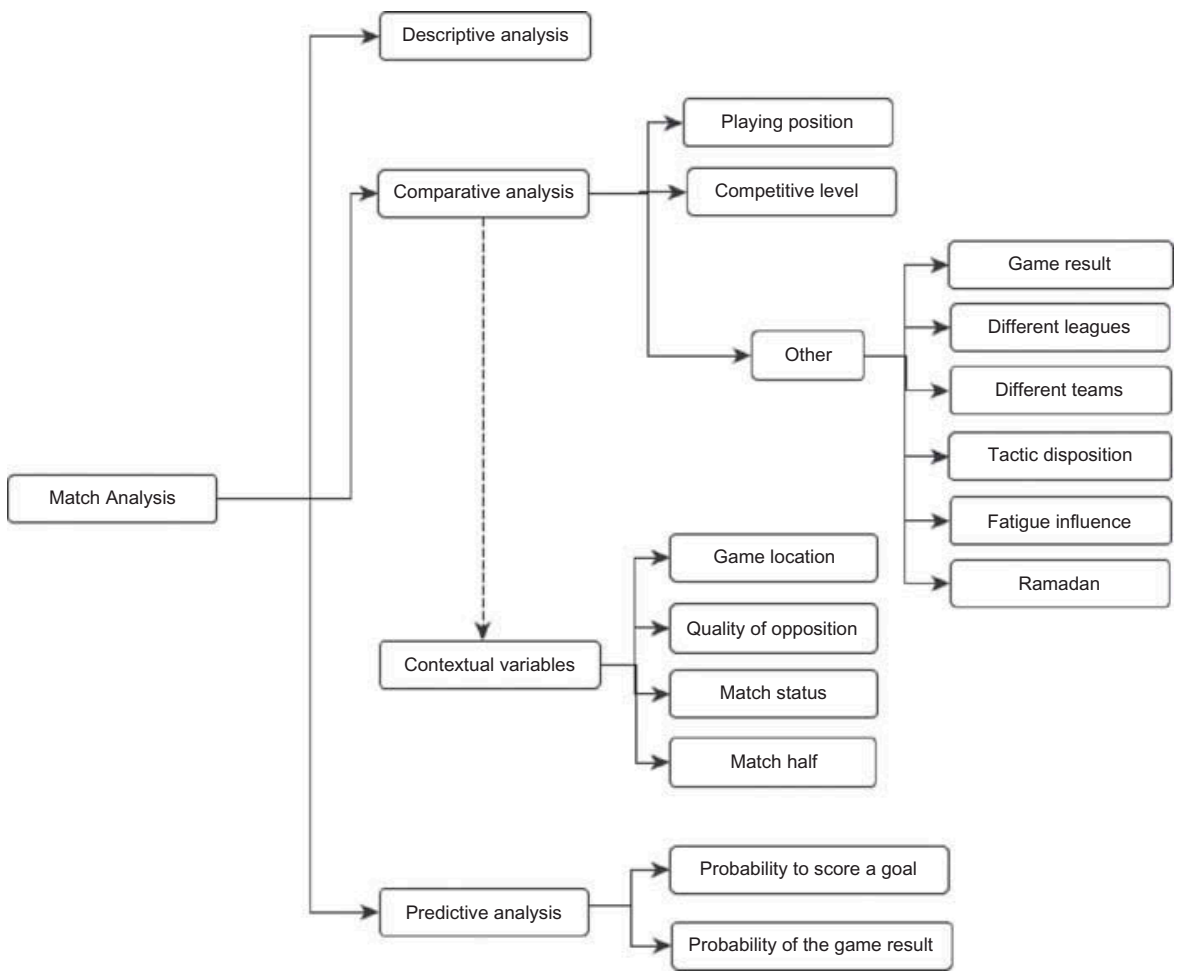

Figure 2. Scopes of match analysis. 
Table I. Empirical studies with predominantly descriptive analysis.

\begin{tabular}{|c|c|c|c|}
\hline Study & Sample & Movement categories & Procedures \\
\hline Barros et al. (2007) & $\begin{array}{l}55 \text { players of First Brazilian } \\
\text { Division }\end{array}$ & $\begin{array}{l}\text { Standing/walking/jogging, low-speed running, } \\
\text { moderate-speed running, high-speed running, } \\
\text { sprinting. }\end{array}$ & $\begin{array}{l}\text { Video analysis of } \\
\text { the activity of } \\
\text { players. }\end{array}$ \\
\hline Di Salvo et al. (2007) & $\begin{array}{l}300 \text { players of Spanish Premier } \\
\text { League }\end{array}$ & $\begin{array}{l}\text { Standing/walking/jogging, low-speed running, } \\
\text { moderate-speed running, high-speed running, } \\
\text { sprinting. }\end{array}$ & $\begin{array}{l}\text { Computerised } \\
\text { match analysis } \\
\text { system } \\
\text { (AMISCO) }\end{array}$ \\
\hline $\begin{array}{l}\text { Rampinini, Coutts, } \\
\text { Castagna, Sassi, and } \\
\text { Impellizzeri (2007) }\end{array}$ & $\begin{array}{l}20 \text { players of a successful team that } \\
\text { participated in a major } \\
\text { European National League }\end{array}$ & $\begin{array}{l}\text { Standing, walking, jogging, running, high-speed } \\
\text { running, sprinting. }\end{array}$ & $\begin{array}{l}\text { Computerised } \\
\text { match analysis } \\
\text { system } \\
\text { (ProZone) }\end{array}$ \\
\hline $\begin{array}{l}\text { Di Salvo, Benito, } \\
\text { Calderon, Di Salvo, } \\
\text { and Pigozzi (2008) }\end{array}$ & $\begin{array}{l}62 \text { goalkeepers of English Premier } \\
\text { League }\end{array}$ & $\begin{array}{l}\text { Walking, jogging, running, high-speed run, sprinting } \\
\text { and total distance. }\end{array}$ & $\begin{array}{l}\text { Computerised } \\
\text { match analysis } \\
\text { system } \\
\text { (ProZone) }\end{array}$ \\
\hline $\begin{array}{l}\text { Bradley, Di Mascio, } \\
\text { Peart, Olsen, and } \\
\text { Sheldon (2010) }\end{array}$ & $\begin{array}{l}110 \text { players of European successful } \\
\text { teams }\end{array}$ & $\begin{array}{l}\text { Standing, walking, jogging, running, high-speed } \\
\text { running, sprinting. }\end{array}$ & $\begin{array}{l}\text { Computerised } \\
\text { match analysis } \\
\text { system } \\
\text { (ProZone) }\end{array}$ \\
\hline $\begin{array}{l}\text { Gregson, Drust, } \\
\text { Atkinson, and Di } \\
\text { Salvo (2010) }\end{array}$ & $\begin{array}{l}485 \text { players of the English Premier } \\
\text { League }\end{array}$ & $\begin{array}{l}\text { Total high-speed running (expressed as both high- } \\
\text { speed running distance completed with the } \\
\text { respective players team in possession and without } \\
\text { possession), high-speed running distance, total } \\
\text { sprint distance. }\end{array}$ & $\begin{array}{l}\text { Computerised } \\
\text { match analysis } \\
\text { system } \\
\text { (ProZone) }\end{array}$ \\
\hline $\begin{array}{l}\text { Vigne, Gaudino, } \\
\text { Rogowski, Alloatti, } \\
\text { and Hautier (2010) }\end{array}$ & 388 players of the Italian Series A & $\begin{array}{l}\text { Walking, jogging, speed below the anaerobic threshold, } \\
\text { speed above the anaerobic threshold, sprint. }\end{array}$ & $\begin{array}{l}\text { Computerised } \\
\text { match analysis } \\
\text { system (SICS) }\end{array}$ \\
\hline Carling (2011) & $\begin{array}{l}21 \text { players of French League } 1 \\
\text { division }\end{array}$ & $\begin{array}{l}\text { Total distance covered in: low-to-moderate intensity; } \\
\text { high intensity; very high intensity. }\end{array}$ & $\begin{array}{l}\text { Computerised } \\
\text { match analysis } \\
\text { system } \\
\text { (AMISCO) }\end{array}$ \\
\hline $\begin{array}{l}\text { Castellano, Blanco- } \\
\text { Villaseñor, and } \\
\text { Álvarez (2011) }\end{array}$ & $\begin{array}{l}434 \text { players of Spanish Premier } \\
\text { League }\end{array}$ & $\begin{array}{l}\text { Standing/walking/jogging, low-speed running, } \\
\text { moderate-speed running, high-speed running, very } \\
\text { high-speed running, sprinting. }\end{array}$ & $\begin{array}{l}\text { Computerised } \\
\text { match analysis } \\
\text { system } \\
\text { (AMISCO) }\end{array}$ \\
\hline $\begin{array}{l}\text { Robinson, } \\
\text { O'Donoghue, and } \\
\text { Wooster (2011) }\end{array}$ & $\begin{array}{l}180 \text { players of the English Premier } \\
\text { League }\end{array}$ & $\begin{array}{l}\text { Path changes of: } 45^{\circ} \text { to } 135^{\circ} \text { to the left; } 45^{\circ} \text { to } 135^{\circ} \text { to } \\
\text { the right; more than } 135^{\circ} \text { to the left or the right. }\end{array}$ & $\begin{array}{l}\text { Computerised } \\
\text { match analysis } \\
\text { system } \\
\text { (ProZone) }\end{array}$ \\
\hline
\end{tabular}

activity patterns (Barros et al., 2007; Bloomfield, Polman, \& O'Donoghue, 2005, 2007; Bradley et al., 2010; Dellal et al., 2011; Dellal, Wong, Moalla, \& Chamari, 2010; Di Salvo et al., 2010, 2007; Di Salvo, Gregson, Atkinson, Tordoff, \& Drust, 2009; Gregson et al., 2010; Kaplan, Erkmen, \& Taskin, 2009; Lago-Peñas, Rey, LagoBallesteros, Casáis, \& Domínguez, 2011; Rampinini et al., 2007; Vigne et al., 2010), frequency of game actions (Bloomfield et al., 2007; Dellal et al., 2010, 2011; Di Salvo et al., 2010, 2009; Rampinini et al., 2007; Vigne et al., 2010) and efficacy of game actions (Dellal et al., 2010, 2011).

The results showed that the demands on the physical and technical realms are different depending on the specific position the player takes in the field, which may enable the development of more insightful and specific training programmes for football players.
Different competitive levels. Match analysis also focused on the performance comparison between different competitive levels. However, due to the different strategies used by different research teams, to structure the competitive levels, it becomes difficult to extrapolate (Table III). More specifically, researchers not only compared competitive levels between different teams in the same competitions according to their final ranking (Hughes \& Franks, 2005; Lago-Ballesteros \& Lago-Peñas, 2010; Rampinini, Impellizzeri, Castagna, Coutts, \& Wisløff, 2009), but also compared players relative to their level of professionalism (defined in accordance with the players' competitive level, who were classified as professional, semi-professional and amateur) (Kaplan et al., 2009; O’Donoghue, Boyd, Lawlor, \& Bleakley, 2001), or as a function of the quality of teams in which they played (Bradley et al., 2010). 
Table II. Comparative studies with predominantly comparative analysis according to the different functional positions of the players.

\begin{tabular}{|c|c|c|c|c|}
\hline Study & Sample & $\begin{array}{l}\text { Categories of player } \\
\text { positions }\end{array}$ & Analysed variables & Main results \\
\hline $\begin{array}{l}\text { Barros et al. } \\
\quad(2007)\end{array}$ & $\begin{array}{l}55 \text { players of First } \\
\text { Brazilian Division. }\end{array}$ & $\begin{array}{l}\text { Central defenders, } \\
\text { external defenders, } \\
\text { central midfield, } \\
\text { external midfield, } \\
\text { forwards. }\end{array}$ & $\begin{array}{l}\text { Distances covered at } \\
\text { different intensities. }\end{array}$ & $\begin{array}{l}\text { The distances covered by external } \\
\text { defenders, central midfielders and } \\
\text { external midfielders were greater } \\
\text { than forwards. The forwards covered } \\
\text { greater distances than central } \\
\text { defenders. }\end{array}$ \\
\hline $\begin{array}{l}\text { Bloomfield et al. } \\
\text { (2007) }\end{array}$ & $\begin{array}{l}55 \text { of the English } \\
\text { Premier League. }\end{array}$ & $\begin{array}{l}\text { Defenders, miedfielders } \\
\text { and forwards. }\end{array}$ & $\begin{array}{l}\text { Purposeful movements } \\
\text { (PM). }\end{array}$ & $\begin{array}{l}\text { The specific position on the field had a } \\
\text { significant influence on \%PM time } \\
\text { spent sprinting, running, shuffling, } \\
\text { skipping and standing still. The } \\
\text { position had no significant influence } \\
\text { on the \%PM time spent performing } \\
\text { movement at low, medium, high or } \\
\text { very high intensities. }\end{array}$ \\
\hline $\begin{array}{l}\text { Di Salvo et al. } \\
\text { (2007) }\end{array}$ & $\begin{array}{l}300 \text { of Spanish } \\
\text { Premier League. }\end{array}$ & $\begin{array}{l}\text { Central defenders, } \\
\text { external defenders, } \\
\text { central midfield, } \\
\text { external midfield, } \\
\text { forwards. }\end{array}$ & $\begin{array}{l}\text { Distances covered at } \\
\text { different intensities. }\end{array}$ & $\begin{array}{l}\text { Midfield players covered a significantly } \\
\text { greater total distance than the groups } \\
\text { of defenders and forwards. The } \\
\text { shortest distance was covered by } \\
\text { central defenders. }\end{array}$ \\
\hline $\begin{array}{l}\text { Rampinini et al. } \\
\text { (2007) }\end{array}$ & $\begin{array}{l}20 \text { players of a } \\
\text { successful team that } \\
\text { participated in a } \\
\text { major European } \\
\text { National League. }\end{array}$ & $\begin{array}{l}\text { Centre-back, fullback, } \\
\text { midfield, forward. }\end{array}$ & $\begin{array}{l}\text { Match activities, match } \\
\text { distances, other match- } \\
\text { analysis measures. }\end{array}$ & $\begin{array}{l}\text { Difference of all variables between } \\
\text { player positions }\end{array}$ \\
\hline $\begin{array}{l}\text { Di Salvo et al. } \\
\text { (2009) }\end{array}$ & $\begin{array}{l}563 \text { of the English } \\
\text { Premier League. }\end{array}$ & $\begin{array}{l}\text { Central defenders, } \\
\text { external defenders, } \\
\text { central midfield, } \\
\text { external midfield, } \\
\text { forwards. }\end{array}$ & $\begin{array}{l}\text { High-intensity running } \\
\text { activity. }\end{array}$ & $\begin{array}{l}\text { The total high-intensity running was } \\
\text { dependent upon playing position } \\
\text { with the external midfielders } \\
\text { completing the highest and lowest } \\
\text { distance, respectively. }\end{array}$ \\
\hline $\begin{array}{l}\text { Dellal et al. } \\
\quad(2010)\end{array}$ & $\begin{array}{l}3540 \text { players of } \\
\text { French League } 1 \\
\text { division. }\end{array}$ & $\begin{array}{l}\text { Central defenders, full- } \\
\text { backs, central } \\
\text { defensive midfielders, } \\
\text { wide midfielders, } \\
\text { central attacking } \\
\text { midfielders, forwards. }\end{array}$ & $\begin{array}{l}\text { Physical parameters } \\
\text { (distances covered in } \\
\text { high intensity and } \\
\text { sprinting, of ground } \\
\text { duels or heading duels } \\
\text { won. Technical } \\
\text { parameters (successful } \\
\text { passes, total duration of } \\
\text { individual ball } \\
\text { possession, number of } \\
\text { touches per individual } \\
\text { possession). }\end{array}$ & $\begin{array}{l}\text { Midfielders performed successful passes } \\
\text { ranging from } 75 \% \text { to } 78 \% \text {, whereas } \\
\text { lower values were found for the } \\
\text { forwards }(71 \%) \text { and central } \\
\text { defenders }(63 \%) \text {, respectively. }\end{array}$ \\
\hline $\begin{array}{l}\text { Di Salvo et al. } \\
\quad(2010)\end{array}$ & $\begin{array}{l}717 \text { players of } \\
\text { Champions League } \\
\text { teams. }\end{array}$ & $\begin{array}{l}\text { Central defenders, } \\
\text { external defenders, } \\
\text { central midfield, } \\
\text { external midfield, } \\
\text { forwards. }\end{array}$ & $\begin{array}{l}\text { Total number of sprints } \\
\text { and total sprint distance } \\
\text { covered. }\end{array}$ & $\begin{array}{l}\text { Differences were found in most of the } \\
\text { analysed variables depending on the } \\
\text { specific position on the field. Wide } \\
\text { midfielders performed a higher } \\
\text { number of sprints in all five distance } \\
\text { categories than all other positions. }\end{array}$ \\
\hline $\begin{array}{l}\text { Vigne et al. } \\
\quad(2010)\end{array}$ & $\begin{array}{l}388 \text { players of the } \\
\text { Italian Series A. }\end{array}$ & $\begin{array}{l}\text { Defenders, miedfielders } \\
\text { and forwards. }\end{array}$ & $\begin{array}{l}\text { Distances covered at } \\
\text { different intensities. }\end{array}$ & $\begin{array}{l}\text { The midfielders covered significantly } \\
\text { more distance than players in other } \\
\text { positions. For midfielders, the } \\
\text { number of displacements of } 2-40 \mathrm{~m} \\
\text { and the number of sprints covering } \\
\text { between } 2 \text { and } 9 \mathrm{~m} \text { and between } 30 \\
\text { and } 40 \mathrm{~m} \text { are considerably greater } \\
\text { than for other positions. }\end{array}$ \\
\hline $\begin{array}{l}\text { Dellal et al. } \\
\quad(2011)\end{array}$ & $\begin{array}{l}5938 \text { of the English } \\
\text { Premier League } \\
\text { and of Spanish } \\
\text { Premier League. }\end{array}$ & $\begin{array}{l}\text { Central defenders, full- } \\
\text { backs, central } \\
\text { defensive midfielders, } \\
\text { wide midfielders, } \\
\text { central attacking } \\
\text { midfielders, forwards. }\end{array}$ & $\begin{array}{l}\text { Distances covered at } \\
\text { different intensities. } \\
\text { Technical parameters. }\end{array}$ & $\begin{array}{l}\text { English Premier League and Spanish } \\
\text { Premier League teams present } \\
\text { differences in various physical and } \\
\text { technical aspects of match play, } \\
\text { suggesting that cultural differences } \\
\text { may exist across professional soccer } \\
\text { leagues and playing positions. }\end{array}$ \\
\hline
\end{tabular}


Table III. Empirical studies with predominantly comparative analysis based on the different competitive levels.

\begin{tabular}{lccc}
\hline Study & Sample & $\begin{array}{c}\text { Number of } \\
\text { considered levels }\end{array}$ & $\begin{array}{c}\text { Strategies used to estab } \\
\text { the levels }\end{array}$ \\
\hline $\begin{array}{l}\text { O'Donoghue } \\
\text { et al. (2001) }\end{array}$ & $\begin{array}{c}72 \text { players of the } \\
\text { English } \\
\text { Championships }\end{array}$ & Three & $\begin{array}{c}\text { Elite, amateurs and semi- } \\
\text { professional players }\end{array}$ \\
& &
\end{tabular}

\begin{tabular}{|c|c|c|c|c|}
\hline $\begin{array}{l}\text { Hughes and } \\
\text { Franks (2005) }\end{array}$ & $\begin{array}{l}116 \text { matches of the } \\
1990 \text { (Italy) and } \\
1994 \text { (USA) } \\
\text { World Cup }\end{array}$ & Two & $\begin{array}{l}\text { Successful teams (quarter- } \\
\text { finalists) and unsuccessful } \\
\text { teams (first round losers) }\end{array}$ & $\begin{array}{l}\text { by the other groups of players. } \\
\text { For successful teams, longer passing } \\
\text { sequences produced more goals per } \\
\text { possession than shorter passing } \\
\text { sequences. For unsuccessful teams, } \\
\text { neither tactic had a clear advantage. }\end{array}$ \\
\hline $\begin{array}{l}\text { Rampinini et al. } \\
\text { (2009) }\end{array}$ & $\begin{array}{l}186 \text { players of the } \\
\text { Italian Series A }\end{array}$ & Two & $\begin{array}{l}\text { Successful teams (ranked in the } \\
\text { first five positions) vs. less } \\
\text { successful teams (ranked in the } \\
\text { last five positions) }\end{array}$ & $\begin{array}{l}\text { The players from the more successful } \\
\text { teams covered greater total distance with } \\
\text { the ball and very high-intensity running } \\
\text { distance and also had more } \\
\text { involvements with the ball, completed } \\
\text { more short passes, successful short } \\
\text { passes, tackles, dribbling, shots, and } \\
\text { shots on target compared to the less } \\
\text { successful teams. }\end{array}$ \\
\hline $\begin{array}{l}\text { Bradley et al. } \\
\quad(2010)\end{array}$ & $\begin{array}{l}110 \text { players of } \\
\text { European } \\
\text { successful teams }\end{array}$ & Two & $\begin{array}{l}\text { Elite domestic players (that played } \\
\text { in teams that compete in one of } \\
\text { the strongest Leagues in the } \\
\text { world) vs. Elite international } \\
\text { players (that played in teams } \\
\text { ranked in the Top } 10 \text { of the } \\
\text { FIFA }\end{array}$ & $\begin{array}{l}\text { No statistical significant differences were } \\
\text { found between the groups for high- } \\
\text { intensity running distance, mean } \\
\text { recovery time or maximal running } \\
\text { speed. }\end{array}$ \\
\hline $\begin{array}{l}\text { Lago-Ballesteros } \\
\text { and Lago- } \\
\text { Peñas (2010) }\end{array}$ & $\begin{array}{l}380 \text { matches of the } \\
\text { Spanish Premier } \\
\text { League }\end{array}$ & Three & According to the final ranking & $\begin{array}{l}\text { Top teams had a higher average of goals for } \\
\text { total shots and shots on goal than middle } \\
\text { and bottom teams. Bottom teams } \\
\text { needed a higher number of shots for } \\
\text { scoring a goal than the other groups of } \\
\text { teams. Middle teams showed a lower } \\
\text { value in assists and ball possession than } \\
\text { top teams. }\end{array}$ \\
\hline
\end{tabular}

Similarly, the researchers characterised the relationships established with the patterns of physical activity (Bradley et al., 2010; Kaplan et al., 2009; O’Donoghue et al., 2001; Rampinini et al., 2009), frequency (Lago-Ballesteros \& Lago-Peñas, 2010; Rampinini et al., 2009) and efficacy (Hughes \& Franks, 2005; Rampinini et al., 2009) of game actions (e.g., involvements with the ball, successful passes, dribbling, shots and shots on target). With the exception of the research conducted by Bradley et al. (2010), in which the authors determine the high-intensity activity patterns in elite domestic and elite international players, these types of studies revealed the existence of several differences related to competitive level. These researches concluded that, overall, the players of more successful teams covered greater total distances with the ball, and at very high-intensity running, had a high average of goals for total shots on target, performed more involvements with the ball, higher number of passes, tackles, dribbling and shots on target when compared with less successful teams (see Table III).

Under this context, a different methodology was reported by Hughes and Franks (2005), which demonstrated the effect of data normalisation on the interpretation of the efficacy of the passing sequences between successful and unsuccessful teams. Data normalisation for the purpose of comparisons is crucial because it enables the analysis of the relative importance of the conversion rates from the different lengths of passing sequences per possession into goals. It is therefore necessary to assess the relative contribution of each possession length from equal frequencies occurrences.

These differences resulting from the different competitive levels of studies may provide useful 
information for coaches who want their players to reach greater levels of performance (O'Donoghue et al., 2001).

Other comparisons. In addition to the nature of comparative studies which focused its analysis on the basis of the functional position of players and competitive level, there were a number of studies that focused their analysis on other aspects, although these were fewer in number.

We found two studies that built the comparative analysis on the basis of the game's end result (LagoPenas, Lago-Ballesteros, Dellal, \& Gomez, 2010; Lago-Peñas, Lago-Ballesteros, \& Rey, 2011). These authors showed that there are game-related statistics like total number of shots, shots on goal, crosses, crosses against and ball possession, venue and quality of opposition that allow to discriminate between winning, drawing and losing teams.

Most of the comparative studies previously presented (see Table III) focused on the quantification of physical-activity profiles of players in a particular league, in contrast with the fewer studies that compared performances between different leagues (Dellal et al., 2011), or in different teams (Papadimitriou, Aggeloussis, Dersi, Michalopoulou, \& Papas, 2001; Papadimitriou, Taxildaris, Alexopulos, Mavromatis, \& Papas, 2001). There were also other studies that aimed at producing other comparisons. These include the influence of fatigue (Carling \& Dupont, 2011; Lyons, AlNakeeb, \& Nevill, 2006; Rey, Lago-Peñas, LagoBallesteros, Casais, \& Dellal, 2010), of an overfilled calendar (Lago-Peñas, Rey, et al., 2011; Rey et al., 2010), of the Ramadan (Zerguini, Kirkendall, Junge, \& Dvorak, 2007), of substitutes and replaced players (Carling, Espié, Le Gall, Bloomfield, \& Jullien, 2010) and the influence of own or opposing team's formation (Bradley et al., 2011; Carling, 2011).

The main finding of these studies suggests that the performance of soccer players was not influenced by short recovery between matches (Carling \& Dupont, 2011), whereas playing formation had effect on some performances. In the study by Bradley et al. (2011), the results suggest that playing formation does not influence the overall activity profiles of players, except for attackers. In line with the latter results, the work by Carling and Dupont (2011) has shown that, overall, physical performance in the reference team was not greatly affected by opposing team's formation. In contrast, skill-related demands varied substantially according to the opponent's formation and may have consequences for tactical and technical aspects and team-selection policies. Further, performance declined significantly for speed, agility, dribbling speed and endurance, remaining low even after the Ramadan (Zerguini et al., 2007).

\section{Predictive Analysis}

Although seldom, these studies with the predictive power were published with some frequency in the last two years (Lago-Penas \& Lago-Ballesteros, 2011; Lago-Penas et al., 2010; Lago-Peñas, Rey, et al., 2011; Tenga, Holme, Ronglan, \& Bahr, 2010a, 2010b; Tenga, Ronglan, \& Bahr, 2010). There were only two studies that were published previously (Hughes \& Franks, 2005; Pollard \& Reep, 1997). The common purpose of this type of studies is to determine the most effective ways of playing. Through the use of multidimensional qualitative data instead of unidimensional frequency data, the ability to describe soccer match play is improved (Tenga et al., 2010a).

From the chronological analysis it came out that the first study in this area was the one by Pollard and Reep (1997). This research team investigated the effectiveness of ball possession, and developed a quantitative variable that represented the probability of a goal being scored, minus the probability of a goal being conceded. More recently, Hughes and Franks (2005), taking as reference the research from Reep and Benjamin (1968), used data normalisation and regression analysis to further explore the results.

Through discriminant analysis, some authors have attempted to identify which game-related statistics allow to discriminate winning, drawing and losing. In a study conducted with 380 games of the Spanish First league, Lago-Penas et al. (2010) inferred that the discriminant functions classified correctly $55.1 \%$ of these teams. The higher discriminatory power variables were the total shots, shots on goal, crosses, crosses against and ball possession. Similarly, through the analysis of 288 of the UEFA Champions League matches, Lago-Peñas et al. (2011) concluded that the discriminant functions correctly classified $79.7 \%$ of winning, drawing and losing teams. The variables that had a higher discriminatory power were shots on goal, crosses, ball possession, venue (home/away) and quality of opposition.

The above-mentioned studies present reference values of game statistics and demonstrate in which aspects of the game there are differences between winning, losing and drawing. This profile can be of help to the coach when preparing training sessions and matches. As stated by Lago-Peñas et al. (2011), scouting for the upcoming opposing team, together with the assessment of post-match performance can be done in a more objective way by establishing the impact of particular variables on team performance.

Additionally, three studies (Tenga et al., 2010a, $2010 \mathrm{~b}, 2010)$ used logistic regression techniques to run the analysis, with two of them (Tenga et al., 
$2010 \mathrm{a}, 2010 \mathrm{~b})$ assessing the interaction context with the opponents. The analysis of this variable (interaction context with the opponents) seems extremely important in the context of match analysis, but surprisingly was not studied in any of the other reviewed studies. Tenga et al. (2010b) investigated the effect of tactics on scored goals in 163 matches of Norwegian professional football league, and concluded that for the main variable "team possession type", counter-attacks were more effective than elaborate attacks when playing against an imbalanced defence. Using the same sample, the authors (Tenga et al., 2010a) examined the effect of playing tactics on score box possession; the latter term is defined as entry into score box (main scoring area in front of the opponent's goal defined as an imaginary extension of the penalty area from 16 to $30 \mathrm{~m}$ of estimated distance to the opponent's goal line) with high degree of control over the ball or when a set play is given to the attacking team as a result of entry into score box. High degree of control over the ball means enough space and time to make it easier to perform the intended action on the ball, and concluded that for the main variable "team possession type" (defined as degree of offensive directness by levels of utilisation or creation of imbalance in the opponent's defence to achieve penetration), counterattacks were more effective than elaborate attacks when playing against an imbalanced defence but not against a balanced one. Lastly, Tenga et al. (2010) examined the relationship between broader measures (scoring opportunities and score box possessions) and the ultimate measure (goals scored) of offensive effectiveness. They concluded that regardless of the outcome measure for offensive effectiveness used, the results stayed similar. The authors highlight that the scoring opportunities and score box possessions can be researched as a proxy for goals scored when comparing the efficiency of different playing tactics in soccer.

They concluded that the results were very similar regardless of which outcome measure for offensive effectiveness was used.

From the above results, although the literature highlights the importance and relevance of this type of research (Gréhaigne \& Mahut, 2001), and despite the constant use of sophisticated analytical techniques in match analysis, there are still few available studies that have worked on developing predictive models of sports performance (Marcelino et al., 2011).

\section{Contextual variables}

Despite strong evidence of the role context plays in other sports-science domains, like motor-skills learning (Magill \& Hall, 1990) or sport psychology
(Strachan, Côté, \& Deakin, 2009), there is little work done on match analysis. This review confirmed the existence of a group of studies that focused their analysis on the comparison of variables related to physical (Carling, 2010, 2011; Carling \& Bloomfield, 2010; Carling \& Dupont, 2011; Castellano et al., 2011; Di Salvo et al., 2007, 2009; Jacklin, 2005; Lago, 2009; Lago et al., 2010; Lago \& Martín, 2007; Lago-Peñas \& Dellal, 2010; LagoPenas \& Lago-Ballesteros, 2011, 2011; O'Donoghue et al., 2001; Pollard, 2006; Poulter, 2009; Rampinini et al., 2007, 2009; Sánchez, García-calvo, Leo, Pollard, \& Gómez, 2009; Taylor, Mellalieu, James, \& Shearer, 2008; Thomas, Reeves, \& Smith, 2006; Vigne et al., 2010) and technical performance (Carling \& Dupont, 2011; Rampinini et al., 2009) in relation to the match half. The genesis of this phenomenon as an object of study is sustained through the principle that fatigue influences the physical and technical performance of the players.

Our results confirmed that a decrement in players' performance in the Italian (Vigne et al., 2010), English (O'Donoghue et al., 2001), French (Carling, 2011; Carling \& Bloomfield, 2010; Carling \& Dupont, 2011) and Spanish leagues (Di Salvo et al., 2007) tends to be observed in the second half of the match. However, this decrement (total distance covered and distances covered at high and very high intensity) is not a phenomenon that occurs systematically; it has instead been associated with the distance covered by players during the first half. The results demonstrated that when players are required to carry out a more intense first half, total distance covered is decreased in the second half. In case of a less intense first half, total distance and high-intensity running distance did not change, and very high-intensity running even increased on the second half. Regarding the technical aspects, Rampinini et al. (2009) observed a decline between the first and second half of the Italian league since players were less involved with the ball, had less short passes and less successful short passes. These data are in contrast with the study by Carling and Dupont (2011) who concluded that there were no significant differences in performance shown by French league midfield players.

When investigating the effects of game location commonly referred to as "home advantage", several studies (Jacklin, 2005; Lago \& Martín, 2007; LagoPenas \& Lago-Ballesteros, 2011; Lago-Penas, LagoBallesteros et al. 2011; Pollard, 2006; Sánchez et al., 2009; Thomas et al., 2006) have confirmed indicators pointing to a more favourable outcome when teams play at home. There is a tendency for teams that play at home to score more goals (Poulter, 2009), perform more shots on goal (Lago-Penas \& 
Lago-Ballesteros, 2011; Poulter, 2009; Taylor et al., 2008), more crossings (Lago-Penas \& LagoBallesteros, 2011; Taylor et al., 2008), more passes, more successful passes, more dribbles with success and to take more corners (Lago \& Martín, 2007; Lago-Peñas \& Dellal, 2010; Lago-Penas \& LagoBallesteros, 2011; Poulter, 2009) compared with teams playing away. In regard to disciplinary behaviour, teams playing at home commit fewer fouls (Poulter, 2009) and receive less yellow cards (Lago-Penas \& Lago-Ballesteros, 2011; Poulter, 2009; Thomas et al., 2006). In general, the results of the reviewed studies showed that a home advantage effect exists for most performance and discipline measures at a team level. These findings indicate that strategies in soccer are influenced by match location and teams may alter their playing style accordingly.

Apart from the aspects related to home advantage and match half, researchers have attempted to study the influence of other contextual aspects, particularly those related to quality of opposition and match status. An increasing tendency (Table IV) for studies to jointly analyse the influence of the mentioned contexts on different variables was observed (Castellano et al., 2011; Lago, 2009; Lago et al., 2010; Lago \& Martín, 2007; Lago-Peñas \& Dellal, 2010; Lago-Peñas, Rey, et al., 2011; Taylor et al., 2008). The results of the later studies showed that there are significant differences based on the quality of the opposition and the ongoing result of the game.

In all the reviewed studies, researchers used categories of match status defined based on the intervals: losing ] $-\infty ;-1]$, drawing [0] and winning $[1 ;+\infty[$, which are considered appropriate for games like football that end with a low score (Marcelino et al., 2011), and they conclude that when losing the teams had more ball possession (Lago, 2009; Lago \& Martín, 2007; Lago-Peñas \& Dellal, 2010) and performed more crosses (Taylor et al., 2008) and dribbles (Taylor et al., 2008). On the other hand, when winning the teams performed: (1) more interceptions, clearances and aerial challenges (Taylor et al., 2008); (2) fewer passes and dribbles (Taylor et al., 2008); (3) and less high-intensity exercises (Lago, 2009; Lago-Peñas, Lago-Ballesteros, et al., 2011).

Regarding the quality of opposition, researchers have opted for the construction of categories based on different parameters. For example, Lago and Martín (2007) classified the groups based on a reference team (e.g., Real Madrid), while Taylor et al. (2008) opted for a symmetrical division based on the final ranking, grounding their analysis on the dichotomy "strong opposition" versus "weak opposition"; still Taylor and colleagues considered that this division did not provide the necessary sensitivity to detect all the differences.
There are other studies (Lago, 2009; Lago et al., 2010; Lago-Peñas \& Dellal, 2010; Lago-Peñas, Rey, et al., 2011) in which the quality of opposition is also classified into "strong" or "weak", but with different meaning. This categorisation is based on the difference between the final league's ranking of the team under study and the final league's ranking of the opponent team. More recent studies consider three (Castellano et al., 2011) or four groups (Lago-Penas \& Lago-Ballesteros, 2011) according to the final position in the league's ranking. In this regard, Marcelino et al. (2011) considered that the construction of groups to analyse the effect of opposition quality must overcome traditional reductionism of symmetrical division based on the final ranking. Alternatively, the latter team of researchers suggested the application of statistical techniques where cluster analysis and independent variables are used.

The studies that focused their analysis on the quality of the opposing teams showed that when playing against strong opponents, they perform more passes (Taylor et al., 2008), less dribble (Taylor et al., 2008) and covered greater distances (Castellano et al., 2011; Lago et al., 2010; LagoPeñas, Lago-Ballesteros, et al., 2011). In addition, playing against strong opponents is associated with a reduction in ball-possession time (Lago \& Martín, 2007; Lago-Peñas \& Dellal, 2010). These findings may be important for coaches, when developing strategic and tactical aspects in order to improve the performance of their teams in relation to the diversity of situational variables that their teams may encounter.

\section{Limitations and recommendations for future research}

Research on match analysis in adult male football has been mainly focused on the description of physical and/or physiological aspects of football and technical game actions as an attempt to quantify the activity of players. However, in most cases, this was done without considering the situational and interactional contexts in which such performances happen/occur.

The reviewed studies have revealed concerns related to a lack of operational definitions and conflicting classifications of activity or playing positions that make it difficult to compare similar group of studies. The integration of comprehensive operational definitions for the analysis variables, the standardisation of the groups established by player positions and the use of the same movement categories are imperative in order to progress to a more comparable and replicable research in the future. 
Table IV. Empirical studies with situational - match status, quality of opposition and match location.

\begin{tabular}{|c|c|c|c|c|}
\hline Study & Sample & Categories & Variables & Results \\
\hline \multirow[t]{3}{*}{$\begin{array}{l}\text { Lago and Martín } \\
\qquad(2007)\end{array}$} & $\begin{array}{l}170 \text { games of the } \\
\text { Spanish First } \\
\text { league }\end{array}$ & $\begin{array}{l}\text { Winning, } \\
\text { drawing, } \\
\text { losing }\end{array}$ & $\begin{array}{l}\text { Percentage of } \\
\text { team } \\
\text { possession }\end{array}$ & $\begin{array}{l}\text { The teams that played at home had more possession than the } \\
\text { teams playing away. }\end{array}$ \\
\hline & & Home vs. away & & $\begin{array}{l}\text { When loosing, teams playing at home had more possession } \\
\text { than when they were drawing or winning. }\end{array}$ \\
\hline & & Reference team & & $\begin{array}{l}\text { The worse the opposing team, the higher was the percentage of } \\
\text { ball possession. }\end{array}$ \\
\hline \multirow[t]{3}{*}{ Taylor et al. (2008) } & $\begin{array}{l}40 \text { games of a } \\
\text { professional } \\
\text { English team }\end{array}$ & $\begin{array}{l}\text { Winning, } \\
\text { drawing, } \\
\text { losing }\end{array}$ & $\begin{array}{l}\text { Technical } \\
\text { behaviours }\end{array}$ & $\begin{array}{l}\text { At winning: teams performed more interception, clearance and } \\
\text { aerial challenge and fewer crosses, passes and dribbles. At } \\
\text { losing: teams made more crosses, dribbles and passes and } \\
\text { fewer clearances and interceptions. }\end{array}$ \\
\hline & & Home vs. away & & $\begin{array}{l}\text { Playing at home, performed more crosses and shots, but fewer } \\
\text { interceptions and tackles. }\end{array}$ \\
\hline & & Strong vs. weak & & $\begin{array}{l}\text { When they played against strong opponents, they performed } \\
\text { more passes and less dribbling. }\end{array}$ \\
\hline \multirow[t]{3}{*}{ Lago (2009) } & $\begin{array}{l}27 \text { games of the } \\
\text { Spanish first } \\
\text { League }\end{array}$ & $\begin{array}{l}\text { Winning, } \\
\text { drawing, } \\
\text { losing }\end{array}$ & $\begin{array}{l}\text { Percentage of } \\
\text { team } \\
\text { possession }\end{array}$ & $\begin{array}{l}\text { Possession was greater when losing than when winning or } \\
\text { drawing. }\end{array}$ \\
\hline & & Home vs. away & & $\begin{array}{l}\text { Playing against strong opponent teams has been associated } \\
\text { with a decrease in time of possession. }\end{array}$ \\
\hline & & Strong vs. weak & & The possession was not influenced by the venue of the game. \\
\hline \multirow[t]{3}{*}{ Lago et al. (2010) } & $\begin{array}{l}27 \text { players of the } \\
\text { First Spanish } \\
\text { League }\end{array}$ & $\begin{array}{l}\text { Winning, } \\
\text { drawing, } \\
\text { losing }\end{array}$ & Work rate & $\begin{array}{l}\text { The players performed less high-intensity exercises when they } \\
\text { were winning. }\end{array}$ \\
\hline & & Home vs. away & & The teams playing at home covered greater distances. \\
\hline & & Strong vs. weak & & $\begin{array}{l}\text { Players covered greater distances when they played against } \\
\text { strong opposition. }\end{array}$ \\
\hline \multirow[t]{3}{*}{$\begin{array}{l}\text { Lago-Peñas and } \\
\quad \text { Dellal (2010) }\end{array}$} & $\begin{array}{l}380 \text { games of the } \\
\text { Spanish First } \\
\text { league }\end{array}$ & $\begin{array}{l}\text { Winning, } \\
\text { drawing, } \\
\text { losing }\end{array}$ & $\begin{array}{l}\text { Percentage of } \\
\text { team } \\
\text { possession }\end{array}$ & $\begin{array}{l}\text { The best ranked teams maintained a high percentage of } \\
\text { possession and their pattern of play was more stable. Time } \\
\text { of possession was greater when teams were losing and when } \\
\text { they played at home. Playing against strong opponents is } \\
\text { associated with a reduction in time of possession. }\end{array}$ \\
\hline & & Home vs. away & & \\
\hline & & Reference team & & \\
\hline \multirow[t]{3}{*}{$\begin{array}{l}\text { Lago-Peñas, Lago- } \\
\text { Ballesteros, et al. } \\
\text { (2011) }\end{array}$} & $\begin{array}{l}172 \text { players of the } \\
\text { Spanish First } \\
\text { league }\end{array}$ & $\begin{array}{l}\text { Winning, } \\
\text { drawing, } \\
\text { losing }\end{array}$ & Work rate & $\begin{array}{l}\text { The elite players performed less high intensity when winning } \\
\text { than when losing. }\end{array}$ \\
\hline & & Home vs. away & & $\begin{array}{l}\text { The teams playing at home covered greater distances at low } \\
\text { intensity than the teams playing away. }\end{array}$ \\
\hline & & Strong vs. weak & & $\begin{array}{l}\text { Players covered a greater distance walking and jogging when } \\
\text { playing against stronger teams }\end{array}$ \\
\hline \multirow[t]{3}{*}{$\begin{array}{l}\text { Castellano et al. } \\
\text { (2011) }\end{array}$} & $\begin{array}{l}434 \text { players of the } \\
\text { Spanish First } \\
\text { league }\end{array}$ & $\begin{array}{l}\text { Winning, } \\
\text { drawing, } \\
\text { losing }\end{array}$ & Work rate & $\begin{array}{l}\text { The total distance covered by players at different intensities } \\
\text { during the effective time of play was higher when playing at } \\
\text { home, when the reference team was losing and when the } \\
\text { opponent team was strong. }\end{array}$ \\
\hline & & Home vs. away & & \\
\hline & & $\begin{array}{l}\text { Strong, medium } \\
\text { and weak }\end{array}$ & & \\
\hline
\end{tabular}

Taking into account that predictive models assume lesser importance in reviewed studies on footballmatch analysis, we agree with Gréhaigne and Mahut (2001) who suggest a crucial need to move beyond the description of behaviours and progress towards prediction of performance. One facet of the prediction of sporting behaviour (i.e., performance) involves examining tactical strategies of individuals or teams with an aim to identify common patterns of behaviour and movement (James, Mellalieu, \& Hollely, 2002).
Attempting to predict future performance on the basis of previous performances is a challenging task yet important for match analysts. Typically the basis for any prediction model is that performance is repeatable, to some degree. In other words, events that have previously occurred will occur again in some predictable manner. This type of prediction is based on the principle that any performance is a consequence of factors like prior learning, inherent skills and situational variables (James, 2012). 


\section{Conclusion}

This work shows how a considerable number of studies on match analysis in adult male football have enabled the general description of technical, tactical and physical variables. Further, there are some studies that have developed their analysis in relation to other categories of comparison like final game score, Ramadan influence, levels of fatigue, different leagues, teams or tactical systems.

A large number of studies have focused their analyses on four main situational variables of performance that seem to assume a greater importance: (1) game location; (2) quality of the opposition; (3) match status and (4) match half. It is noteworthy that the new methodological advances have enabled overcoming some of the typical match-analysis limitations (O'Donoghue, 2010) as well as improving ways of establishing groups regarding quality of opposition (Marcelino et al., 2011).

Further, with the help of advanced statistical procedures, some researchers have attempted to find some association between cause and effect in different interactional contexts. However, such studies on possible interactions between analysis variables have only recently been in the agenda of researchers. This research review showed that match-analysis work has been predominantly done using simple description and associations between variables, thus investigating this phenomenon without considering the dynamic, interactive and complex systems' aspects that can better characterise match performance in football (Balague, Torrents, Hristovski, Davids, \& Araújo, 2013; Sampaio \& Maçãs, 2012).

The main limitations of the reviewed studies are related to a lack of operational definitions, conflicting classifications of activity or playing positions, and limited studies that consider interactional context in their analyses. Future research should: (1) provide comprehensive operational definitions for the analysis variables, (2) use standardised categories and classifications of activities and participants and (3) consider integrating in the analysis the situational as well as interactional contexts in which the performances happen.

The football game has evolved over the years, together with the development of computer systems that enable a more in-depth understanding of this performance phenomenon. A current challenge involves creating suitable video sequences that can clearly identify and categorise individuals and behaviours over time and regular playing patterns. To this end, we recommend the adoption of methodologies that include situational (match location, match status, quality of opposition, match half), continuous and sequential aspects of the game, so that the science of match analysis can be more readily applied in the field, as commented elsewhere (Drust \& Green, 2013).

\section{Funding}

The authors gratefully acknowledge the support of the Portuguese Foundation for Science and Technology [SFRH/BD/45736/2008].

\section{References}

Balague, N., Torrents, C., Hristovski, R., Davids, K., \& Araújo, D. (2013). Overview of complex systems in sport. Fournal of Systems Science E Complexity, 26(1), 4-13.

Barros, R., Misuta, M., Menezes, R., Figueroa, P., Moura, F., Cunha, S., ... Leite, N. (2007). Analysis of the distances covered by first division Brazilian soccer players obtained with an automatic tracking method. Fournal of Sports Science and Medicine, 6(2), 233-242.

Bloomfield, J., Polman, R., \& O'Donoghue, P. (2005). Effects of score-line on team strategies in FA Premier League soccer. fournal of Sport Sciences, 23(2), 192-193.

Bloomfield, J., Polman, R., \& O’Donoghue, P. (2007). Physical demands of different positions in FA Premier League soccer. Fournal of Sports Science and Medicine, 6(1), 63-70.

Bradley, P., Carling, C., Archer, D., Roberts, J., Dodds, A., Di Mascio, M., ... Krustrup, P. (2011). The effect of playing formation on high-intensity running and technical profiles in English FA Premier League soccer matches. fournal of Sports Sciences, 29(8), 821-830.

Bradley, P., Di Mascio, M., Peart, D., Olsen, P., \& Sheldon, B. (2010). High-intensity activity profiles of elite soccer players at different performance levels. Fournal of Strength and Conditioning Research, 24(9), 2343-2351.

Carey, D., Smith, G., Smith, D., Shepherd, J., Skriver, J., Ord, L., \& Rutland, A. (2001). Footedness in world soccer: An analysis of France '98. Fournal of Sports Sciences, 19(11), 855-864.

Carling, C. (2010). Analysis of physical activity profiles when running with the ball in a professional soccer team. Fournal of Sports Sciences, 28(3), 319-326.

Carling, C. (2011). Influence of opposition team formation on physical and skill-related performance in a professional soccer team. European fournal of Sport Science, 11(3), 155-164.

Carling, C., \& Bloomfield, J. (2010). The effect of an early dismissal on player work-rate in a professional soccer match. fournal of Science and Medicine in Sport, 13(1), 126-128.

Carling, C., \& Dupont, G. (2011). Are declines in physical performance associated with a reduction in skill-related performance during professional soccer match-play? fournal of Sports Sciences, 29(1), 63-71.

Carling, C., Espié, V., Le Gall, F., Bloomfield, J., \& Jullien, H. (2010). Work-rate of substitutes in elite soccer: A preliminary study. Fournal of Science and Medicine in Sport, 13(2), 253-255.

Carling, C., Reilly, T., \& Williams, A. (Eds.). (2009). Performance assessment for field sports. London: Routledge.

Carling, C., Williams, A., \& Reilly, T. (Eds.). (2005). The handbook of soccer match analysis: A systematic approach to improving performance. Abingdon: Routledge.

Castellano, J., Blanco-Villaseñor, A., \& Álvarez, D. (2011). Contextual variables and time-motion analysis in soccer. International fournal of Sports Medicine, 32(6), 415-421.

De Baranda, P., Ortega, E., \& Palao, J. (2008). Analysis of goalkeepers' defence in the World Cup in Korea and Japan in 2002. European fournal of Sport Science, 8(3), 127-134.

Dellal, A., Chamari, K., Wong, D., Ahmaidi, S., Keller, D., Barros, R., ... Carling, C. (2011). Comparison of physical 
and technical performance in European soccer match-play: FA Premier League and La Liga. European fournal of Sport Science, 11(1), 51-59.

Dellal, A., Wong, D. P., Moalla, W., \& Chamari, K. (2010). Physical and technical activity of soccer players in the French First League - With special reference to their playing position. International Sportmed fournal, 11(2), 278-290.

Di Salvo, V., Baron, R., González-Haro, C., Gormasz, C., Pigozzi, F., \& Bachl, N. (2010). Sprinting analysis of elite soccer players during European Champions League and UEFA Cup matches. Fournal of Sports Sciences, 28(14), 1489-1494.

Di Salvo, V., Baron, R., Tschan, H., Calderon Montero, F., Bachl, N., \& Pigozzi, F. (2007). Performance characteristics according to playing position in elite soccer. International fournal of Sports Medicine, 28(3), 222-227.

Di Salvo, V., Benito, P., Calderon, F., Di Salvo, M., \& Pigozzi, F. (2008). Activity profile of elite goalkeepers during football match-play. Fournal of Sports Medicine and Physical Fitness, 48 (4), 443-446.

Di Salvo, V., Gregson, W., Atkinson, G., Tordoff, P., \& Drust, B. (2009). Analysis of high intensity activity in Premier League Soccer. International Fournal of Sports Medicine, 30(3), 205-212.

Drust, B., Atkinson, G., \& Reilly, T. (2007). Future perspectives in the evaluation of the physiological demands of soccer. [Review]. Sports Medicine, 37(9), 783-805.

Drust, B., \& Green, M. (2013). Science and football: Evaluating the influence of science on performance. Fournal of Sports Sciences, 31(13), 1377-1382.

Gregson, W., Drust, B., Atkinson, G., \& Di Salvo, V. (2010). Match-to-match variability of high-speed activities in Premier League soccer. International fournal of Sports Medicine, 31(4), 237-242.

Gréhaigne, J., \& Mahut, B. (2001). Qualitative observation tools to analyse soccer. International fournal of Performance Analysis in Sport, 1(1), 52-61.

Hughes, M. \& Franks, I. (Eds.). (1997). Notational analysis of sport. London: E\&F Spon.

Hughes, M., \& Franks, I. (2004a). Notational analysis - A review of the literature. In M. Hughes \& I. Franks (Eds.), Notational analysis of sports - Systems for better coaching and performance in sport. London: Routlege.

Hughes, M., \& Franks, I. (2004b). Notational analysis of sport IImproving coaching and performance in Sport. London: E\&FN Spon.

Hughes, M., \& Franks, I. (2005). Analysis of passing sequences, shots and goals in soccer. Fournal of Sports Sciences, 23(5), 509-514.

Hughes, M. \& Franks, I. (Eds.). (2008). The essentials of performance analysis - An introduction. London: Routledge.

Jacklin, P. (2005). Temporal changes in home advantage in English football since the Second World War: What explains improved away performance? fournal of Sports Sciences, 23(7), 669-679.

James, N. (2006). Notational analysis in soccer: Past, present and future. International Fournal of Performance Analysis in Sport, 6 (2), 67-81.

James, N. (2012). Predicting performance over time using a case study in real tennis. Fournal of Human Sport and Exercise, 7(2), 421-433.

James, N., Mellalieu, S., \& Hollely, C. (2002). Analysis of strategies in soccer as a function of European and domestic competition. International Fournal of Performance Analysis in Sport, 2, 85-103.

Kaplan, T., Erkmen, N., \& Taskin, H. (2009). The evaluation of the running speed and agility performance in professional and amateur soccer players. Fournal of Strength and Conditioning Research, 23(3), 774-778.

Lago, C. (2009). The influence of match location, quality of opposition, and match status on possession strategies in professional association football. Fournal of Sports Sciences, 27 (13), 1463-1469.

Lago, C., Casais, L., Dominguez, E., \& Sampaio, J. (2010). The effects of situational variables on distance covered at various speeds in elite soccer. European fournal of Sport Science, 10(2), 103-109.

Lago, C., \& Martín, R. (2007). Determinants of possession of the ball in soccer. Fournal of Sports Sciences, 25(9), 969-974.

Lago-Ballesteros, J., \& Lago-Peñas, C. (2010). Performance in team sports: Identifying the keys to success in soccer. Fournal of Human Kinetics, 25, 85-91.

Lago-Peñas, C., \& Dellal, A. (2010). Ball possession strategies in elite soccer according to the evolution of the match-score: The influence of situational variables. Fournal of Human Kinetics, 25, 93-100.

Lago-Penas, C., \& Lago-Ballesteros, J. (2011). Game location and team quality effects on performance profiles in professional soccer. Fournal of Sports Science and Medicine, 10(3), 465-471.

Lago-Penas, C., Lago-Ballesteros, J., Dellal, A., \& Gomez, M. (2010). Game-related statistics that discriminated winning, drawing and losing teams from the Spanish soccer league. fournal of Sports Science and Medicine, 9(2), 288-293.

Lago-Peñas, C., Lago-Ballesteros, J., \& Rey, E. (2011). Differences in performance indicators between winning and losing teams in the UEFA Champions League. Fournal of Human Kinetics, 27, 135-146.

Lago-Peñas, C., Rey, E., Lago-Ballesteros, J., Casáis, L., \& Domínguez, E. (2011). The influence of a congested calendar on physical performance in elite soccer. Fournal of Strength and Conditioning Research, 25(8), 2111-2117.

Lyons, M., Al-Nakeeb, Y., \& Nevill, A. (2006). Performance of soccer passing skills under moderate and high-intensity localized muscle fatigue. Fournal of Strength and Conditioning Research, 20(1), 197-202.

Magill, R., \& Hall, K. (1990). A review of the contextual interference effect in motor skill acquisition. Human Movement Science, 9, 241-289.

Marcelino, R., Mesquita, I., \& Sampaio, J. (2011). Investigação centrada na análise do Jogo: Da modelação estática à modelação dinâmica. Revista Portuguesa De Ciências Do Desporto, 11(1), 481-499.

O'Donoghue, P. (Ed.). (2010). Research methods for sports performance analysis. London: Routledge.

O’Donoghue, P., Boyd, M., Lawlor, J., \& Bleakley, E. (2001). Time-motion analysis of elite, semi-professional and amateur soccer competition. Fournal of Human Movement Studies, 41(1), $1-12$.

Papadimitriou, K., Aggeloussis, N., Dersi, V., Michalopoulou, M., \& Papas, M. (2001). Evaluation of the offensive behavior of elite soccer teams. Perceptual and Motor Skills, 93(2), 405-415.

Papadimitriou, K., Taxildaris, K., Alexopulos, P., Mavromatis, G., \& Papas, M. (2001). Defensive actions of finalist soccer teams in 18(th) World Cup in France. Fournal of Human Movement Studies, 41(2), 125-139.

Pollard, R. (2006). Worldwide regional variations in home advantage in association football. fournal of Sports Sciences, 24(3), 231-240.

Pollard, R., \& Reep, C. (1997). Measuring the effectiveness of playing strategies at soccer. Statistician, 46(4), 541-550.

Poulter, D. (2009). Home advantage and player nationality in international club football. Fournal of Sports Sciences, 27(8), 797-805.

Rampinini, E., Coutts, A., Castagna, C., Sassi, R., \& Impellizzeri, F. (2007). Variation in top level soccer match performance. International fournal of Sports Medicine, 28(12), 1018-1024.

Rampinini, E., Impellizzeri, F., Castagna, C., Coutts, A., \& Wisløff, U. (2009). Technical performance during soccer matches of the Italian Serie A league: Effect of fatigue and 
competitive level. Fournal of Science and Medicine in Sport, 12(1), 227-233.

Reep, C., \& Benjamin, B. (1968). Skill and chance in association football. Fournal of the Royal Statistical Society. Series A (General), 134, 581-585.

Reilly, T. (Ed.). (1977). Science and soccer. London: E\&FN Spon.

Rey, E., Lago-Peñas, C., Lago-Ballesteros, J., Casais, L., \& Dellal, A. (2010). The effect of congested fixture period on the activity of elite soccer players. Biology of Sport, 27(3), 181-185.

Robinson, G., O'Donoghue, P., \& Wooster, B. (2011). Path changes in the movement of English Premier League soccer players. Fournal of Sports Medicine and Physical Fitness, 51(2), 200-226.

Sampaio, J., \& Maçãs, V. (2012). Measuring tactical behaviour in football. International fournal of Sports Medicine, 33(5), 395-401.

Sánchez, P., García-calvo, T., Leo, F., Pollard, R., \& Gómez, M. (2009). An analysis of home advantage in the top two Spanish Professional Football leagues. Perceptual and Motor Skills, 108 (3), 789-797.

Strachan, L., Côté, J., \& Deakin, J. (2009). An evaluation of personal and contextual factors in competitive youth sport. fournal of Applied Sport Psychology, 21(3), 340-355.
Taylor, J., Mellalieu, S., James, N., \& Shearer, D. (2008). The influence of match location, quality of opposition, and match status on technical performance in professional association football. Fournal of Sports Sciences, 26(9), 885-895.

Tenga, A., Holme, I., Ronglan, L., \& Bahr, R. (2010a). Effect of playing tactics on achieving score-box possessions in a random series of team possessions from Norwegian professional soccer matches. Fournal of Sports Sciences, 28(3), 245-255.

Tenga, A., Holme, I., Ronglan, L., \& Bahr, R. (2010b). Effect of playing tactics on goal scoring in Norwegian professional soccer. Fournal of Sports Sciences, 28(3), 237-244.

Tenga, A., Ronglan, L., \& Bahr, R. (2010). Measuring the effectiveness of offensive match-play in professional soccer. European fournal of Sport Science, 10(4), 269-277.

Thomas, S., Reeves, C., \& Smith, A. (2006). English soccer teams' aggressive behavior when playing away from home. Perceptual and Motor Skills, 102(2), 317-320.

Vigne, G., Gaudino, C., Rogowski, I., Alloatti, G., \& Hautier, C. (2010). Activity profile in Elite Italian Soccer Team. International Fournal of Sports Medicine, 31(5), 304-310.

Zerguini, Y., Kirkendall, D., Junge, A., \& Dvorak, J. (2007). Impact of Ramadan on physical performance in professional soccer players. British fournal of Sports Medicine, 41(6), 398-400. 